\title{
NOTICIAS ARTÍSTICAS DE LA CIUDAD DE MURCIA BAJO EL PRISMA DE UN ILUSTRADO: CORRESPONDENCIA ENTRE DIEGO ANTONIO REJÓN DE SILVA Y JOSÉ VARGAS PONCE
}

\section{NEWS ON HERITAGE IN THE AGE OF ENLIGHTENMENT: EPISTOLARY RELATION BETWEEN DIEGO ANTONIO REJÓN DE SILVA AND JOSÉ VARGAS PONCE}

\author{
Alejandro Jaquero Esparcia \\ Universidad de Castilla-La Mancha
}

\begin{abstract}
RESUMEN
El artículo propone mostrar el interés generado desde la óptica ilustrada por los elementos artísticos y monumentales mediante las redes epistolares de dos ilustrados que contribuyeron al asentamiento de las Bellas Artes en España, por medio de sus diversas aportaciones teóricas, y también, por su interés en conocer y valorar el arte español. En concreto, exponemos un ejemplo del intercambio intelectual mantenido por Diego Antonio Rejón de Silva y José Vargas Ponce. A través de una de las cartas fruto de la relación entre ambas personalidades se arroja más luz sobre los intereses de Vargas Ponce en la ciudad de Murcia y en su legado artístico.

Palabras Clave: Diego Antonio Rejón de Silva / José Vargas Ponce / Epistolografía/ Bellas Artes / Siglo XVIII
\end{abstract}

\section{ABSTRACT}

The following article proposes to show the interest generated from the perspective illustrated by the artistic knowledge through epistolary networks. Specifically, we present an example of this circumstance generated by Diego Antonio Rejón de Silva and José Vargas Ponce. Enlightened men who collaborated in the establishment of the Fine Arts in Spain through their various theoretical collaborations and also showed their interest in knowing and valuing the Spanish heritage. Through one of the letters resulting from the relationship of intellectual exchange between both personalities sheds more light on the interests of Vargas Ponce in the artistic heritage of the city of Murcia.

Keywords: Diego Antonio Rejón de Silva / José Vargas Ponce / Epistolography / Fine Arts / Eighteenth Century 
En los intercambios de información relativa a los bienes monumentales y artísticos mantenidos por los intelectuales y aficionados del siglo XVIII fue más que notable la consolidación de amplias redes epistolares. Un proceso que ha sido, y continúa siendo, un gran espacio de estudio de la historiografía dieciochesca ${ }^{1}$. Aunque el sistema no se limita a esta época, los resultados que se extraen para el desarrollo de la primitiva Historia del Arte del territorio español fueron fundamentales durante el Siglo de las Luces ${ }^{2}$. De hecho, gracias a dichas relaciones se han podido recuperar escritos de gran valor. Sírvanos de ejemplo la edición por parte de Juan Agustín Ceán Bermúdez en su Diccionario histórico de los más ilustres profesores de las bellas artes en España (1800) de los discursos y debates teóricos de Pablo de Céspedes compuestos a finales del siglo XVI y comienzos del XVII; una serie de obras en torno a las artes, arqueología, poesía y otros temas humanísticos generados a través del marco de las relaciones epistolares mantenidas con Francisco Pacheco, Pedro de Valencia, Juan Fernández Franco o Fernando de Herrera ${ }^{3}$. En este sentido, la relación del género epistolar en la composición de obras referentes de la literatura artística europea estuvo vinculada desde los orígenes de la disciplina. En las Lezzione (1549) de Benedetto Varchi las respuestas aportadas a la pregunta sobre la primacía de las artes son efectuadas mediante el uso de este medio de comunicación. De igual modo, Giovanni Gaetano Bottari en la Raccolta di lettere sulla pittura, scultura et architettura, scritte da' più celebri professori che in dette arti fiorirono dal secolo XV al XVII (1754) o las Lettere pittoriche perugine o sia ragguaglio di alcune memorie istoriche risgardanti le arti del disegno in Perugia de Baldassare Orsini (1788) ofrecen una panorámica de la exposicion y recopilación de datos en torno a las Bellas Artes a través de este medio ${ }^{4}$. A propósito de la correspondencia motivada por el interés en el estado de las artes en España, en las siguientes páginas queremos incidir en la relación epistolar mantenida por dos personalidades que, si bien no ejercieron de forma profesional desempeños propios derivados de la actividad artística, su afición hacia estas materias los llevó a colaborar en torno a su construcción teórica e histórica. Nos referimos a José Vargas Ponce y Diego Antonio Rejón de Silva.

De forma previa hemos de señalar algunos aspectos que nos ayuden a contextualizar nuestro objeto de estudio. A lo largo del Setecientos asistiremos en el reino español a la construcción de una serie de procesos sociales y culturales en los que la función de la palabra escrita adquirió un mayor grado de relevancia. Se propiciaría la edición e intercambio de publicaciones -con el gran impacto que supuso la consolidación de la prensa periódica-, la creación de pequeñas bibliotecas personales, la consolidación de colecciones artísticas junto con la de instrumentos técnicos y avances científicos; como bien ha estudiado Jesusa Vega, ese particular nexo entre lo científico y artístico favoreció la confección de los particulares gabinetes ilustrados, espacios de sociabilización privados que se complementaron con la sociabilidad pública promovida por las tertulias o los diferentes eventos públicos de carácter artístico como las exposiciones y muestras académicas (2005: 191-226; 2010: 30-31 y 87-93). Así, esta intensa actividad cultural fomentaría un habitual tráfico de correspondencia en aras de demandar noticias o datos sobre diversidad de aspectos científicos o artísticos, motivando la elaboración de epistolarios de carácter público y privado. La actividad epistolar generada

1 Un repaso de las principales publicaciones dedicadas a los estudios del siglo XVIII en nuestro país nos hará percatarnos de los numerosos textos dedicados a la investigación sobre dichas fuentes, básicas en la construcción de discursos históricos, políticos, económicos, culturales e incluso climatológicos. De hecho, se han dedicado sendos monográficos al tema en las revistas Historia Moderna de la Universidad de Alicante ( $\mathrm{n}^{\circ}$ 18, 1999-2000) y en Cuadernos de Ilustración y Romanticismo de la Universidad de Cádiz $\left(\mathrm{n}^{\circ} 21,2015\right)$, titulado este último "Cartas y epistolarios. Cultura de la correspondencia misiva y práctica editorial”. A riesgo de cometer considerables ausencias, aportamos algunas referencias ilustrativas que se recogen en la bibliografía final (Mestre Sanchís, 2000: 13-26; Castillo Gómez, 2011: 19-50; Andreu Candela, 2019: 13-36).

2 Acerca de la primitiva historiografía del arte en España véase el texto de Úbeda de los Cobos (1995: 123-125). No obstante, como ha sido puesto de relieve por la profesora Vega González en el recorrido que plantea por los orígenes y evolución de la disciplina en el territorio español, dicho proceso sufrió el descrédito de una parte de la historiografía posterior al vincularse a diversas cuestiones peyorativas ligadas, en especial, a los procesos reformistas de la Ilustración (2016: 27-28, 61-62 y 88-89).

3 Algunos fueron publicados en el apéndice del tomo V. La gran parte de este material epistolar ha sido estudiado por Jesús Rubio Lapaz (1993: 259-476).

4 Otros ejemplos en esta misma línea son los trabajos de Michelangelo Gualandi Nuova raccolta di lettere sulla pittura, scultura ed architettura scritte da più celebri personaggi dei secoli XV a XIX con note ed illustrazioni (1844) y Gaetano Milanesi Lettere d'artisti italiani dei secoli XIV e XV raccolte ed annotate (1869), a lo que debemos sumar las reflexiones historiográficas sobre el género desarrolladas desde el ambito italiano (Barocchi, 1984: 83-111; Parlato, 2019: 299-312). 
durante la Ilustración española nos ha aportado interesantes casos de estudio: autores de la talla de Benito Jerónimo Feijoo, Gaspar Melchor de Jovellanos, Nicolás de Azara, Francisco Pérez Bayer, Juan Pablo Forner, Gregorio Mayans y Siscar, entre otros muchos eruditos y hombres de letras a los que no mencionamos por no excedernos en este breve comentario introductorio la practicaron regularmente. A través de las relaciones mantenidas por dichas personalidades se pueden reconstruir los pasos de la configuración de la cultura ilustrada; de hecho, el análisis de sus respectivas correspondencias nos hará percatarnos de la variedad e internacionalidad de sus discusiones -Mayans y Voltaire o Azara y Bodoni, por ejemplo-, buscando la integración en el territorio español de las innovaciones alcanzadas en el debate cultural europeo por medio de sus colegas extranjeros (Cook, 1996: 5-29; Mestre Sanchís, 2003: 267-288; Arias de Saavedra Alías, 2009: 15-61; Álvarez Barrientos, 2013: 17-46; Castillo Gómez, 2014: 25-56; López Souto, 2019: 309-337). Incluso la influencia de la carta se trasladó al campo de lo literario, asentándose como recurso de gran valor en la transmisión de ideas o la creación de relatos: desde los ejemplos franceses en los que destacan la novela de Pierre Chaderlos de Laclos Las Amistades peligrosas (1782) a las Cartas Marruecas de José Cadalso (1789). La carta, fuera de sus usos más privados donde los tonos satíricos o amigables se entremezclan en la transmisión informativa, se utilizó como método sucinto de exposición de ideas, intercambio de información y, en definitiva, como una manera clara de trasladar un discurso ajustado a una reflexión concreta.

Como decíamos, podemos afirmar que el género epistolar tuvo una especial significación a la hora de establecer redes de eruditos e investigadores que trataron de profundizar en diversas particularidades del conocimiento, colaborando en la construcción del panorama intelectual hispano en general y el artístico en particular. Así, trabajos monumentales como los Viajes de España (1772-94) de Antonio Ponz se vieron enriquecidos con los comentarios críticos de colaboradores que fueron transmitidos al autor por vía epistolar (Crespo Delgado, 2012: 95-104). En esta misma línea hemos de situar la extensa labor de Ceán Bermúdez y su ya mencionado Diccionario, obra que pudo ser confeccionada y acrecentada ampliamente por la red de colaboradores que mantuvo, como el autor se encargar de justificar y agradecer en el prólogo. Mediante la búsqueda in situ en los archivos, la visita de los espacios monumentales para comprobar el estado y el cómo se habían aplicado las artes en su desarrollo ornamental o los viajes formativos con el fin de confirmar noticias asentadas por la tradición de la literatura artística previa; de este modo, se realizó una tarea que posibilitó la aportación de datos fidedignos y reconfiguró el conocimiento sobre los artistas y su legado, plasmándose uno de los mayores ejercicios de historiografía artística llevados a cabo hasta la fecha en el territorio hispano (Portela Sandoval, 1978: 191-208; Úbeda de los Cobos, 2001: 372-376; García López, 2016: 100-103; Crespo Delgado, 2017: 407-414; Crespo Delgado, 2018: 419-428)5. En definitiva, los temas más significativos tratados en las cartas por aquellos que buscaron iniciar el discurso histórico de las artes en España serían la preocupación por establecer un conocimiento fidedigno de los artífices hispanos y sus orígenes, el catálogo de sus obras, la reivindicación de los ejemplos más sobresalientes o la denuncia de otros que se alejaban de los criterios estéticos por los que se abogaba en el Setecientos. Sírvannos como ejemplo las noticias que Justino Matute y Gaviria le enviaría a Ceán sobre aspectos literarios, arquitecturas efímeras y otras reflexiones sobre obras artísticas de la ciudad de Sevilla y proyectos en los que se hallaba inmerso; además, le facilita una serie de breves apuntes sobre artistas, aunque muchas no serían incorporadas en el trabajo de Ceán (Portela Sandoval, 1981: 183-192). Dentro de este contexto es donde debemos situar el valor documental de la carta enviada por Rejón de Silva a Vargas Ponce (1796). De hecho, ambas personalidades mantuvieron una fluida comunicación y colaboraron en diversos proyectos orientados al asentamiento y progreso de las Bellas Artes, la conservación del legado monumental y la divulgación de las noticias en materia de bienes artísticos albergados en el territorio español.

5 Otros ilustrados también reflejarían en sus epistolarios inquietudes por las Bellas Artes, el desarrollo e implantación en el territorio español o sus procedimientos más prácticos, tal y como ocurre con los ya mencionados Jovellanos o Feijoo, pero también cabe citar a artistas como Francisco Preciado de la Vega y Francisco de Goya, o políticos como Pedro Rodríguez de Campomanes, Manuel de Roda, Eugenio Llaguno, entre otros muchos (Tellechea Idígoras, 1969: 51-76; Gállego, 1993: 169-178; García Sánchez, 2007: 9-92; Gracia Menéndez, 2016: 27-50). 
Vargas Ponce contribuyó al debate intelectual del XVIII desde diferentes campos del saber. Desde su posición de militar vinculado a la Armada Española, ingresó en los principales focos académicos hispanos: Real Academia de la Historia, Real Academia de Bellas Artes de San Fernando y la Real Academia Española. En lo que se refiere a su discurso de ingreso en la Academia de Bellas Artes, pronunció una disertación sobre la historia y actualidad del arte del grabado, de gran interés dada la escasa literatura artística sobre esta técnica en nuestro país. De igual modo, en el ámbito de la Academia de la Historia pronunció una oración a favor de la cultura española -Apología de la literatura española en las ciencias y bellas artes presentada a la Real Academia de la Historia, leída en 1785-, con especial énfasis en las Bellas Artes (Franco Rubio, 2004: 43-45). Fruto de esta laboriosa actividad académica, Vargas Ponce generó un cuantioso legado epistolar. Solamente el conservado en el archivo de la Academia de la Historia, compuesto por una multitud de testimonios, nos sirve para hacernos una idea general de su prolífica labor (Abascal Palazón y Cebrián Fernández, 2010: 427-565). De hecho, ha sido en esta institución donde se han recuperado parte de los intercambios epistolares mantenidos en los inicios del siglo XIX con Ceán Bermúdez acerca de los bienes artísticos de Guipúzcoa, aportando valiosas noticias en torno a los artífices y teóricos (Marqués de Seoane, 1905: 5-60). Igualmente, en una de las recientes investigaciones de García López sobre el Diccionario de Ceán se han reiterado las palabras de agradecimiento recogidas a lo largo del prólogo de la obra con Vargas Ponce, agradeciendo las noticias que le proporcionó de los templos de Murcia y Cartagena (Fernandez Duro, 1900: 11-12; García López, 2015: $131)^{6}$. Gracias a este tipo de documentación se ha podido comprobar la aportación en los grandes proyectos historiográficos de la literatura artística hispana: recopilación de datos, aportación de reflexiones críticas o investigación de noticias a través de otros circuitos informadores. Es aquí donde podemos enmarcar su relación con Diego Antonio Rejón de Silva y la correspondencia que mantuvieron en torno al estado y legado de las artes en la ciudad de Murcia.

En lo concerniente a la realidad biográfica de Diego Antonio Justo Rejón de Silva y Barciela (1754-1796) han sido escasas las aportaciones desde la esclarecedora publicación de Peña Velasco, zanjando las controversias entre su figura y la del que fuera su padre Diego Ventura Rejón de Silva y Lucas, más relacionado con el campo de la literatura dieciochesca. El hijo del literato estuvo inmerso en una red social mucho más amplia, dando como resultado la participación en numerosas empresas culturales de corte ilustrado (Peña Velasco, 1985: 17-21). La personalidad del padre fue vital para inclinar al hijo a recibir una educación basada en las humanidades, consolidándose posteriormente en estudios de letras y ciencias. Previo paso por el ejército, el principal trabajo que desempeñó en Madrid y desde el que pudo alcanzar renombre en los círculos intelectuales fue dentro de la estructura del Estado, bajo la administración de Floridablanca. Durante toda su vida estuvo vinculado a instituciones que promovieron el avance de la cultura española, al igual que Vargas Ponce. El 5 de noviembre de 1780 fue nombrado académico de honor de la Real Academia de Bellas Artes de San Fernando, pasando a ser consiliario el 2 de febrero de 1787; ingresó en la Real Academia Española, ocupando el sillón X de la institución el 9 de febrero de 1786; también obtuvo un puesto de académico de honor en la Academia de Bellas Artes de San Carlos de Valencia (León Tello y Sanz Sanz, 1980: 324-325). Hemos de situar el ideario artístico de Rejón de Silva en la línea de los ilustrados españoles de mediados del Setecientos, siendo un defensor de las artes bajo las directrices academicistas: a grandes rasgos, un seguimiento de los criterios neoclásicos -propugnados por Winckelmann y difundidos por Mengs en España- en la búsqueda de la belleza ideal extraída del mundo clásico, conjugado con la apología de la tradición artística española del Siglo de Oro. Aspectos que se podrían considerar antitéticos, pero que fueron configurando y conviviendo en un periodo que se encuentra en constante transformación tratando de superar la herencia del Barroco, adaptar los conceptos clasicistas europeos y, como otros autores volverían a plantear y pese a hallarse entre los preceptos renacentista, la

6 Encontrándose este artículo en proceso de edición para su publicación, García López ha publicado un interesante trabajo con la correspondencia entre Vargas Ponce y Ceán Bermúdez, recogiéndose las noticias generadas sobre Murcia y Cartagena (2020: 34-45). 
reivindicación de la naturaleza como maestra a emular, siempre que se haga de una forma idealizadora y no literal, para no caer en el naturalismo; un posicionamiento particular que lo vinculaba a un cierto grupo de ilustrados, dándonos una idea de la variedad y complejidad de la construcción estética y la configuración del gusto dieciochesco (Henares Cuéllar, 1977: 105-107; Úbeda de los Cobos, 2001: 289-300; Jacobs, 2001: 233-244; Álvarez Cebrián, 2005: 235248; Álvarez Cebrián: 2015). No obstante, su teoría artística se puede asimilar de mejor forma analizando los escritos sobre las artes que editó y anotó a lo largo de su vida, donde mantuvo una actividad prolífica. Ya en 1784 vería la luz su recurrida traducción de los tratados de Leonardo da Vinci y León Battista Alberti -elaborada a partir de la edición de Raphael Trichet du Fresne del año 1651-; en 1786 se publicaba La Pintura: Poema didáctico en tres cantos; y en 1788 el Diccionario de las Nobles Artes para Instrucción de los Aficionados, y uso de los Profesores. Aún se podrían incluir otros proyectos que, lamentablemente, quedaron manuscritos, tales como la revisión y edición del tratado de Palomino o la traducción de la Historia del arte de los antiguos de Winckelmann ${ }^{7}$.

Retomando el punto de encuentro de ambos protagonistas, los dos personajes ya habían establecido contactos para elaborar actividades literarias y artísticas antes de la carta sobre el estado de las artes en Murcia. Así, mientras Rejón de Silva formaba parte de la Secretaría de Estado, estuvieron vinculados a un proyecto derivado de la Real Calcografía de Madrid8. Floridablanca le encomendaría la gestión editorial de la colección Retratos de Españoles Ilustres con un epitome de sus vidas, cargo que desempeñaría hasta el año 1792 en el que fue cesado, junto a otros de los protegidos por Floridablanca'. Se han recuperado diferentes cartas y escritos en torno a las descripciones y apuntes que el propio Rejón de Silva indicó sobre la composición del texto, el diseño que debían seguir las estampas o las diferentes opiniones sobre los grabados ya confeccionados (Molina, 2016: 43-60). Fue en el desempeño de esta empresa cultural donde Rejón de Silva y Vargas Ponce mantuvieron posturas enfrentadas. Durán López recoge varias de las cartas cruzadas por ambos caballeros en las que se pueden leer fuertes discrepancias, todo ello debido a la publicación de la biografía de Gonzalo Fernández de Córdoba "El Gran Capitán”; Vargas Ponce no terminaba de ceñirse a las directrices de tamaño del texto que Rejón, como director de la publicación, le exigía para la obra, generándose un intercambio de disconformidades entre uno y otro, que finalmente sería resuelto con la devolución del epítome a Vargas para una posterior publicación (1997: 129-131).

\section{1. "UNA LIGERA DESCRIPCIÓN DE LAS COSAS BUENAS EN MATERIA DE ARQUITECTURA Y PINTURA QUE HAY AQUI'". CRÍTICA DE ARTE DESDE LA ÓPTICA ILUSTRADA}

Con el título del epígrafe se inicia la carta enviada por Rejón a su colega el 18 de marzo de 1796. Conocemos su existencia porque fue recogida por Cesáreo Fernández Duro en la publicación Correspondencia epistolar de D. José Vargas Ponce y otros en materias de arte (1900); el documento original se encuentra en la biblioteca-archivo de la Real Academia de la Historia junto con el resto de las cartas manuscritas con las que elaboró su trabajo. Fue mencionada de manera sucinta por Alfonso E. Pérez Sánchez para justificar la presencia del arquitecto

7 Los datos biográficos utilizados por la Academia en la noticia necrológica del propio Rejón narran las aportaciones: "un compendio del Museo Pictórico de don Antonio Palomino” y "una traducción de la historia de las Artes del célebre antiquario Winckelmann" (Distribución de los premios concedidos por el rey nuestro señor á los discípulos de las tres nobles artes, hecha por la Real Academia de San Fernando en la Junta pública de 13 de Julio de 1799. Madrid: Viuda de Ibarra, 22-23). La particular traducción del texto de Winckelmann, a partir de la edición francesa elaborada por Gottfried Sellius en 1784, ha sido editada por Alejandro Martínez Pérez (Winckelmann, 2014: XV-XXX). Debemos añadir la colaboración emprendida con Antonio Ponz en la censura de la traducción del Vitrubio: "Fue Censor por comisión de la Academia en su Junta particular de 8 de Agosto de 1784, juntamente con el Señor Ponz de la traduccion castellana de Vitruvio, que hizo el Señor Ortiz (José Ortiz y Sanz), y se imprimio en la Imprenta Real” (Distribución de los premios...1799, 23). Faltaría anotar su colaboración como traductor, pero no en obras de carácter artístico. Tradujo junto a Esteban Aldebert Dupon y José Moreno los cinco volúmenes de las Disertaciones de la Academia Real de las Inscripciones y Buenas Letras de París (1782-1785); también desempeñó dicha labor en un compendio de tácticas militares del ingeniero Jean Charles de Folard (Peña Velasco, 1985: 55; Lepinette, 1999: 213).

8 Rejón pudo dirigir la publicación del primer cuaderno compuesto por las efigies de Antonio de Leiva, Ambrosio de Morales, Juan de Mariana, Lope de Vega, Antonio de Solís y Nicolás Antonio (Carrete Parrondo, 1976: 211-216).

9 El 14 de agosto de ese mismo año sería apartado por la nueva dirección del conde de Aranda, junto a otros de sus compañeros como José Casteló o el conde de Castañeda (Romero Peña, 2012: 39-40). 
Ventura Rodríguez en las labores de diseño de la iglesia murciana de San Lorenzo, puesto que sería el propio Rejón de Silva el que llevase las trazas a Murcia desde Madrid (1976: 300-301). Peña Velasco, en su estudio biográfico del personaje, también aludió al escrito y, además, elaboraría una breve descripción de su contenido, valorando los poco acertados comentarios incluidos por el autor (1985: 35). Juan Manuel Abascal y Rosario Cebrián abordan la relevancia de la correspondencia mantenida por ambos en su estudio monográfico sobre Vargas Ponce y la Real Academia de la Historia; de igual modo, David García López también describe parte de su contenido y lo pone en relación con la transmisión de información a Ceán Bermúdez (2010: 82; 2015: 135). Por desgracia, no hemos hallado ni tenemos constancia de una carta previa en la cual Vargas Ponce solicitase las materias de las que pretendía obtener información; no obstante, y puesto que sabemos de los proyectos académicos y relacionados con las Bellas Artes en los que estaba involucrado, podemos pensar que le requería una descripción general de obras singulares de la ciudad de Murcia acordes con el buen gusto ilustrado. Desde 1796 a 1797, a lo largo de nueve meses, el propio Vargas Ponce ampliaría toda esta información afincándose en la ciudad y pasando largas estancias en Cartagena, aplicándose a la recopilación de información para su manuscrita y no publicada Descripción de Cartagena (Durán López, 1997: 27) ${ }^{10}$. Lamentablemente, no se podía contar con una referencia angular como era el caso de la obra de Ponz, puesto que el autor había fallecido antes de poder iniciarse en el estudio del sureste peninsular. Por lo tanto, era necesario recopilar todas las noticias posibles por parte de informadores que tuvieran una mínima formación o interés en el campo de las Bellas Artes.

Las noticias aportadas por Rejón, si bien fueron muy escuetas y no llegan a profundizar en la totalidad del legado artístico de la urbe, adquieren un valor especial al ser una subjetiva y condicionada elección. Optó por ofrecer un discurso en el que sobresaliesen sus preferencias estéticas y las características artísticas valoradas por la cultura ilustrada, tal y como hemos señalado anteriormente. De este modo, en lo referente a los monumentos civiles destacó el Palacio del Almudí. Fue alabado por los paralelismos con la arquitectura renacentista hispana, llegando a afirmar que "sin duda, se hizo por dibujos del célebre Juan de Herrera" (Fernández Duro, 1900: 66). Analizó las estancias internas describiendo el número de columnas, las medidas, el orden arquitectónico de aquellas y la función mercantil del conjunto con el "pórtico saliente para vender los granos á cubierto", refiriéndose a la sobria y funcional ampliación llevada a cabo en 1748 por Jaime Bort (Peña Velasco, 1994: 173-180; Candel Crespo, 2005: 129-136). En general, en esta brevísima enumeración de detalles del edificio, Rejón de Silva valoró de forma especial las similitudes con los arquetipos renacentistas y los modelos clásicos, la funcionalidad del espacio y la belleza a través de la limpieza ornamental que lo configura.

Tras abordar este conjunto civil pasó a enumerar los elementos escultóricos más sugerentes desde su punto de vista, comenzando un particular recorrido por el interior del conjunto catedralicio: "en punto de escultura, la capilla de los Junterones en la Catedral, y una Virgen de mármol que hay en el claustro, son muy buenos" (Fernández Duro, 1900: 66). Es interesante subrayar su intencionado silencio ante la presencia de la Capilla de los Vélez, monumento arquitectónico singular, pero vinculado a una estética goticista por la que Rejón no muestra un mayor interés. En este caso no se posicionaría en el punto de otros ilustrados como Jovellanos, Feijoo e incluso en algunos aspectos, sobre todo lo arquitectónico, el propio Ponz, los cuales sí hallaron motivos de estima en el arte medieval (Azcárate, 1966: 528-532; Rodríguez G. de Ceballos, 2004: 45-53). La arquitectura y ornamentación de esta otra capilla catedralicia mostraba el eco de las innovaciones renacentistas del mundo italiano reflejadas en el territorio español, pero alejándose del purismo clasicista desarrollado en el siglo XVIII. Así, Gil Rodríguez de Junterón, promotor de la obra, quiso adaptar el estilo de su obra a la renovada estética all'antico del Cinquecento (Villela, 2002: 81-102; Suárez Quevedo, 2004: 117-119). De este modo,

10 "No pudiendo resistir el mar, pasó Vargas, harto fatigado del pecho, á Murcia. En una misión de nueve meses visitó casi todo este reino; vió el famoso pantano de Lorca, formó su plano, observó quanto estuvo á su alcance, registró con esmero los archivos públicos, acopió muchos documentos para la vida de Cascales, de D. Diego de Saabedra Faxardo y otros eruditos de aquel pays, para la del célebre escultor Sarcillo y otros artistas, cuyos apuntes remitió á Cean, como este mimo ha publicado, y de varios modos enriqueció Vargas su colección diplomática, que empezó á formar en Sevilla” (Fernández Duro, 1894: 517-518). 


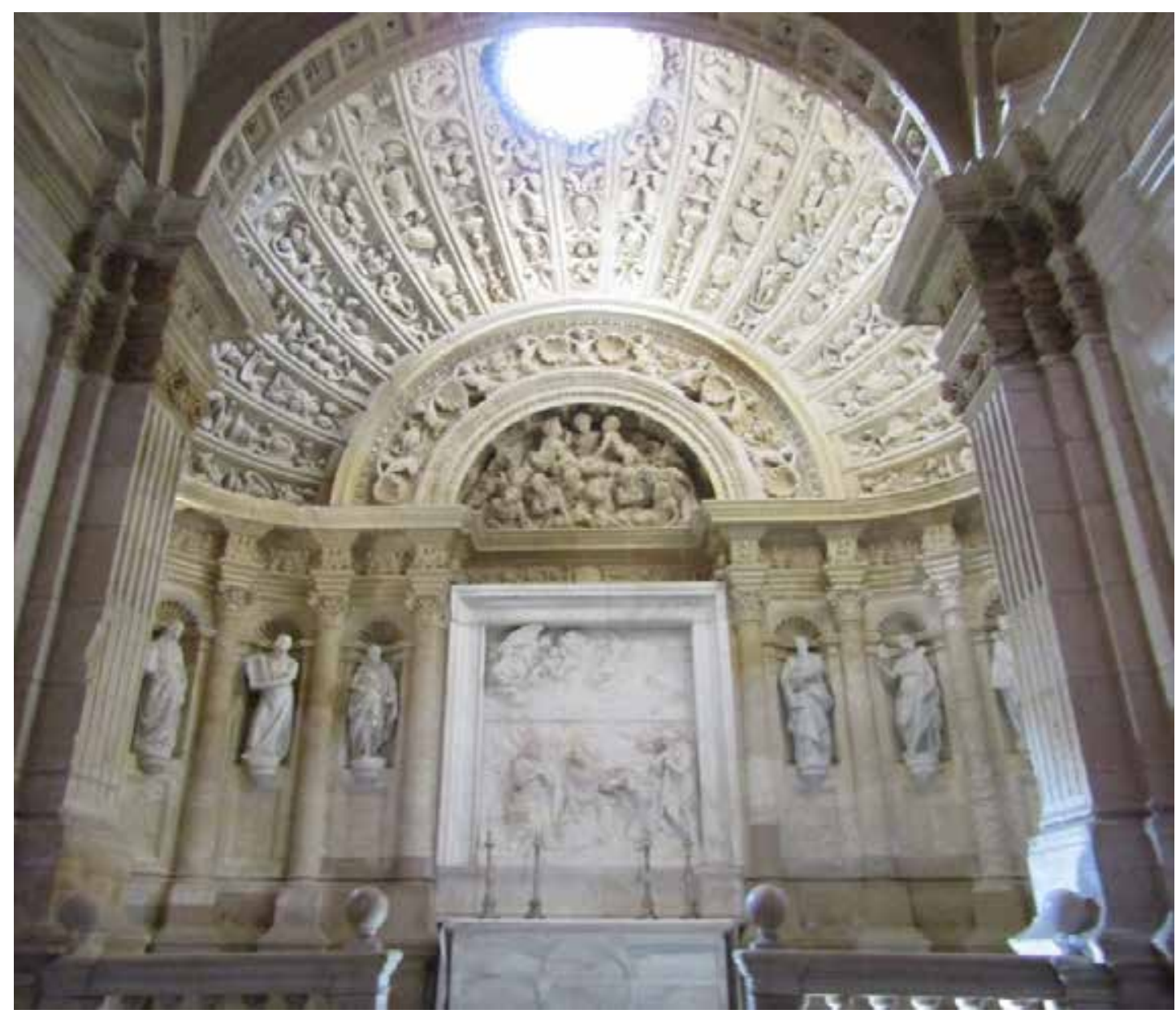

FIGURA 1. Detalle de la Capilla de los Junterones. S. XVI. Catedral de Murcia. Fotografía propia

Rejón de Silva lo valoró como un espacio destacable; las características de la obra iniciada por Jacobo Florentino y finalizadas por Jerónimo Quijano responden a unos valores arquitectónicos meritorios y dignos de ser reseñados entre las obras más significativas del conjunto catedralicio (Gutiérrez-Cortines Corral, 1987: 174-185; Nieto Alcaide, Morales y Checa Cremades, 1997: 144145). En concreto, alabó de manera general la estatuaria y relieves que conforman este espacio: el conjunto de santos y de sibilas donde se entremezclan lo religioso y profano, el frontal de altar marmóreo y los demás ornamentos donde se atisba una clara influencia de las corrientes artísticas italianas (Belda Navarro y Hernández Albaladejo, 2006: 180-181). Por lo que respecta a la estatuaria, junto al conjunto descrito es nombrada la imagen de una Virgen de mármol que debía hallarse en el claustro; quizá esta imagen podría corresponder a la que hoy en día se encuentra en el Museo de la Catedral. La escultura encaja dentro de los criterios estéticos que pretende subrayar Rejón de Silva y en la cronología en la que se realizan las descripciones ${ }^{11}$.

Seguidamente incluye las piezas más relevantes en torno al arte pictórico. De este modo, sobresalen los siguientes ornamentos artísticos en el espacio descrito como "la capilla del Sagrario":

Un quadro del gran Rafael de Urbino, que representa los desposorios de la Santísima Virgen con San Josef; se ven San Joaquin y Santa Ana, y en un semicírculo que forma el marco en la parte superior se ve de medio cuerpo al Padre Eterno, con tiara, bendiciendo aquel puro enlace. Un descanso de Nuestra Señora con el Niño, al lado de la Epístola, y una figura de Nuestro Señor Jesucristo, vestido con ropa talar, con dos corderos á los pies, que parecen vivos, y unos en los hombros, y ambos son del gran Murillo (Fernández Duro, 1900: 66-67).

11 Jorge Aragoneses señaló ya entre los fondos del Museo Diocesano que "del siglo XVI se conservan una preciosa Virgen con Niño, en mármol”. No obstante, se necesitaría contrastar esta evidencia con pruebas documentales más certeras (1959: 268). 


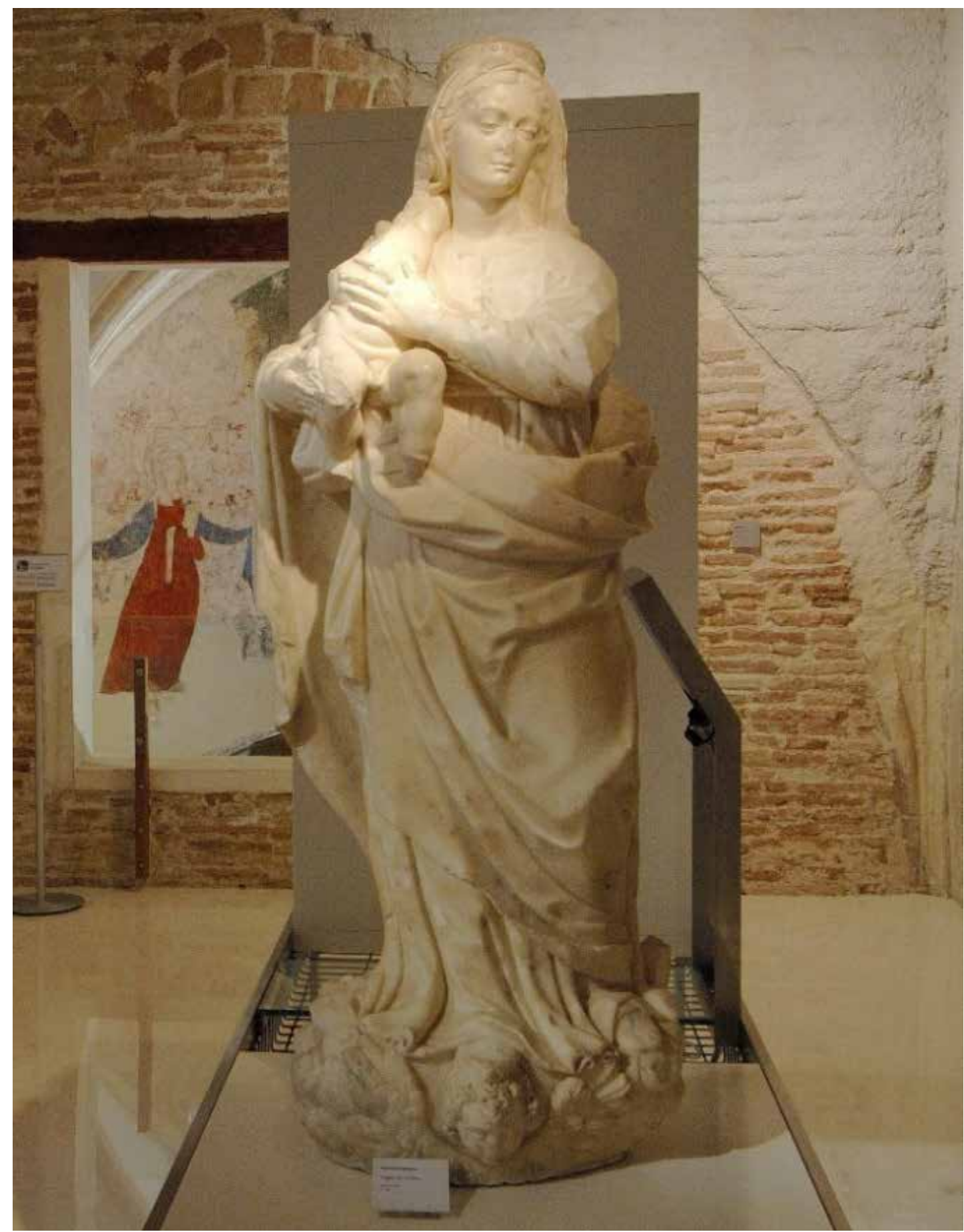

FIGURA 2. Virgen con El Niño. S. XVI. Catedral de Murcia. Fuente: Joaquín Zamora. @ Museo de la Catedral de Murcia

Las atribuciones aportadas por Rejón de Silva cuando menos pudieran parecernos arriesgadas, puesto que están basadas en su conocimiento artístico y caudal visual. Debido a la complejidad interpretativa que conlleva la sumaria descripción, en primer lugar, debemos cerciorarnos de forma correcta sobre el lugar al que se está mencionando, con el fin de acercarnos a la realidad histórica y espacial de las obras. De este modo, los únicos objetos o espacios que pueden aportarnos datos específicos son el sagrario y el espacio de la Epístola. En la catedral murciana el sagrario principal se encontraba desde mediados del XVI en adelante localizado en el retablo renacentista, sustituyendo la anterior elaboración goticista de la capilla mayor, hasta su destrucción durante el incendio de 1854 (Nadal Iniesta, 2018: 128-129). Por todo ello, podríamos dilucidar que las obras sugeridas por Rejón de Silva debieron ser aquellas que conformaban la decoración quinientista de la Capilla Mayor. Sabemos que la obra tuvo durante su segunda etapa de creación, definida por el profesor Cristóbal Belda Navarro, la 


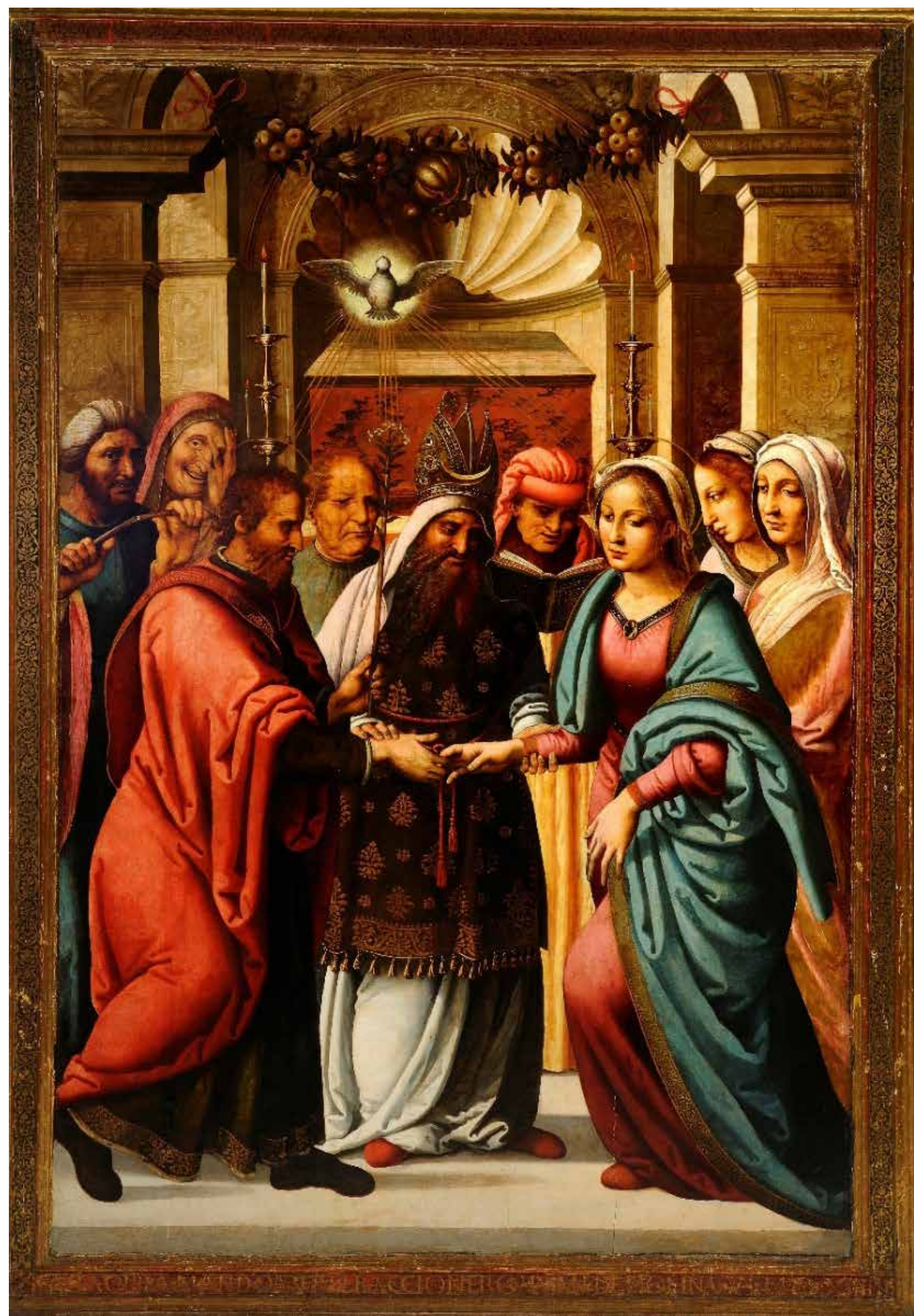

FIGURA 3. Hernando de Llanos. S. XVI. Catedral De Murcia. Fuente: Joaquín Zamora. @ Museo de la Catedral de Murcia

participación en labores pictóricas de Hernando de Llanos junto a sus colaboradores Andrés de Llanos y Jerónimo de Lanza (1974: 5-19). Sin embargo, Belda Navarro apuesta firmemente por la inexistencia de pintura en la ornamentación del retablo, siendo esta una obra exclusiva de escultura y arquitectura, para lo que sustenta su argumentación en las crónicas y opiniones de González Simancas, Bertaux -ambos partidarios de la presencia de elementos pictóricos-, Madoz, Díaz Cassou, Sánchez Moreno o Baquero Almansa, junto a otros aportes documentales que testifican la magnificencia de la estatuaria del retablo (Reyes, 1968: 78-80). 
Es por ello por lo que debemos pensar en otra posibilidad a la hora de localizar esta obra. Atendiendo a otro de los detalles descriptivos sobresale la atribución a Rafael. Ahora bien, una de las pocas descripciones literarias sobre las pinturas que propusieron una equiparación similar fue la elaborada por Juan Antonio de La Riva y Gómez, recogida por posteriores autores como Sánchez Moreno o Antonio de los Reyes (1947: 367-371; 1968: 8283). Se refiere con adjetivos similares a los de Rejón a la tabla de los Desposorios de Fernando o Hernando de Llanos, atribuida también a Yáñez de la Almedina, que se encontraba en la Capilla de San Antonio o del Corpus, albergándose en la actualidad en el Museo de la Catedral.

De este modo, la narración de Rejón de Silva describe a la perfección la composición de este cuadro: se aportan los detalles de la escena principal y la imagen de Dios en la parte superior de la tabla. Asimismo, el cuadro es una buena obra pictórica muy próxima a los cánones renacentistas que el autor trató de localizar y dar a conocer al interesado Vargas Ponce, llegando su admiración, algo desmedida, a asociarla con el propio Rafael; la tabla muestra características italianizantes cercanas a la esfera de Leonardo, pero con serias alteraciones de perspectiva y comprensión del estilo tal y como reafirman los profesores Marías o Ibáñez Martínez (1989: 270-276; 1999: 305-307). Las otras dos imágenes mencionadas, instaladas en el lado de la epístola y asociadas con Bartolomé Esteban Murillo, son unos cuadros de "El Descanso de Nuestra Señora" y "Nuestro Señor Jesucristo", el último ataviado con "ropa talar". En el primer caso la escena se relaciona con el suceso de la huida a Egipto. Las escasas referencias aportadas unidas al peregrino parangón con las obras de Murillo no nos permiten ahondar en la realidad y ubicación de estas dos pinturas, quizá desaparecidas o fruto de juicios interpretativos de un mal observador (Vega González, 2010: 93-96).

De nuevo, Rejón de Silva incluye en su particular selección artística elaborada para Vargas Ponce unas obras recogidas en espacios más definidos. Dentro de la Capilla de los Vélez, y sin hacer mención al espacio arquitectónico, recalca el óleo principal de San Lucas, junto a "otros seis quadros de tamaño regular que son, por lo prolixo, del célebre Leonardo de Vinci” (Fernández Duro, 1900:67). Las asignaciones de Rejón vuelven a ser meras percepciones acordes más a su gusto personal que a la realidad, demostrando una formación de diletante de la pintura basada más en sus lecturas que en el conocimiento práctico de la disciplina o en la propia historia del conjunto monumental. Así, el cuadro de grandes dimensiones que preside la capilla en el cual aparece San Lucas retratando a la Virgen, lo asigna a las labores del pintor valenciano Juan Conchillos y lo ubica en una línea estilística que trataba de emular a Murillo. No hallamos en Palomino, Ceán Bermúdez o Marcos Antonio Orellana una mención concreta de Conchillos y su elaboración de este cuadro para la catedral, por lo que hemos de pensar que la atribución parte del propio Rejón.

Un error importante puesto que, según la inscripción que acompaña la tabla, se puede ver que la obra fue elaborada por Francisco García en el año $1607^{12}$. Pese a que el autor se halla sujeto a una generación transicional, puede que la vinculación con la estética del pintor sevillano sugerida por Rejón de Silva se deba al observar un estilo en consonancia con los modelos contrarreformistas, unido a una base visual inspirada en estampas italianas y flamencas; todo ello se halla en una línea cercana a las producciones de otros artistas murcianos en contacto directo con la escuela valenciana (Pérez Sánchez, 2010: 390-397). De igual modo, indica la presencia de una imagen de la Inmaculada Concepción que, localizada en el trascoro catedralicio, fue parangonada con las creaciones de Mengs. La imagen, "primorosamente pintada" y "de cuerpo entero" coincide con la actual escultura emplazada en el nicho del trascoro catedralicio. Es interesante ver el que, si bien no está hablando de una pintura, la talla barroca -procedente de talleres madrileños- estimuló la alabanza de Rejón acerca de su calidad artística (Sánchez-Rojas Fenoll, 1987: 1535-1545). Puede que el marco arquitectónico patrocinado por el obispo fray Antonio Trejo en el que se halla, profusamente decorado con mármoles y siguiendo una escenografía de corte clasicista, emuladora de las obras italianas, hiciesen a Rejón de Silva valorar de manera positiva todo el conjunto (Rivas

12 La inscripción, recogida por Baquero Almansa en su Catálogo, advierte lo siguiente: "Siendo Pontífice Máximo Paulo V, reinando Felipe III, por mandado del marqués D. Pedro Faxardo de Requesens pintaba este retablo Francisco García su pintor, que se acabó y se sento en 15 de octubre de 1607” (1913: 76; Agüera Ros, 1994: 74). 


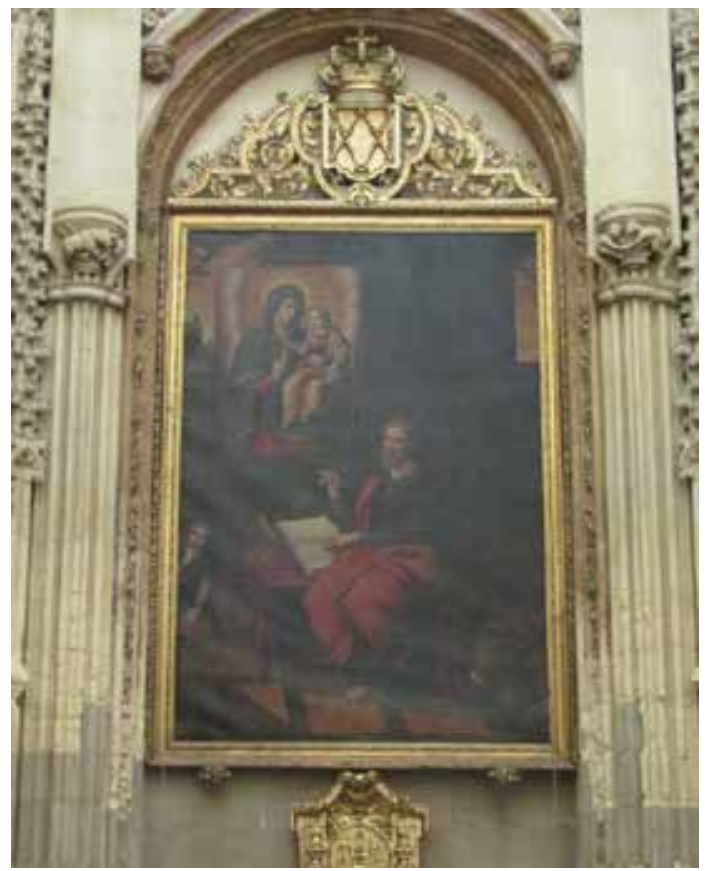

FIGURA 4. Francisco García. San Lucas Retratando a La Virgen y El Niño. C. 1607. Catedral de Murcia. Fotografía propia
Carmona y Cabello Velasco, 1990-1991: 133142; Belda Navarro y Hernández Albaladejo, 2006: 223-227).

Para finalizar las referencias a la catedral y siguiendo la línea descriptiva propuesta, señaló el espacio arquitectónico notable dentro de "la capilla hecha al beato Fr. Andres Ibernon". El conjunto fue fundado en el año 1791 y ornamentado bajo los criterios artísticos derivados del academicismo ilustrado (Belda Navarro, 1986: 279-300). Si partimos de las noticias aportadas por Rejón de Silva, se atribuye la autoría del diseño a una figura académica: "cuyo altar dibuxó el sobrino del célebre arquitecto director de la Real Academia de San Fernando con el mayor gusto, y corresponde con el ornamento arquitectónico de la dicha capilla" (Fernández Duro, 1900: 67). Tal y como señaló Manuel Pérez Sánchez, el doctoral La Riva recibió el encargo de entablar comunicación con la Real Academia de Bellas Artes de San Fernando con el propósito de conseguir renovados proyectos y modelos de altares clasicistas para estas nuevas capillas, remozando, además, las existentes bajo los preceptos academicistas. Gracias a estas peticiones se han vinculado variados diseños de cierta relevancia, como el de Manuel Martín Rodríguez para el tabernáculo de la capilla mayor. De este modo, Martín Rodríguez, sobrino de Ventura Rodríguez, fue asociado por Rejón de Silva con la confección del retablo (Pérez Sánchez, 1995: 72-73 y 83-86). De nuevo, la noticia vuelve a estar basada en apreciaciones subjetivas. Las investigaciones de Belda Navarro y Manuel Pérez Sánchez han expuesto la participación en el diseño de esta obra del murciano Ginés Ruiz, colaborador del pintor de arquitecturas fingidas Paolo Sirtori, con las respectivas intervenciones de talla, jaspeados y ensamblaje a Diego Cubillas, Salvador Ginestar, José Molino y José Amoraga. Ahora bien, sí nos parece que Rejón pudiera estar al tanto de las demandas catedralicias a la Academia en cuestiones referidas al ornato del templo.

Fuera del edificio catedralicio no remarcó demasiadas obras, salvo una serie de construcciones religiosas que le parecen dignas de ser destacadas: "la parroquia de San Antolín, la de San Nicolás, la iglesia de las monjas de Santa Ana, las de las Verónicas, las de Santa Isabel y San Antonio", junto a las de San Agustín y la de la Misericordia. Un conjunto de templos en los que se ejecutaron diversas modificaciones, totales o parciales, durante el siglo XVIII que las aproximaron al buen gusto clasicista. Ahora bien, en dichos templos perduraron características propias de la estética barroca levantina entremezcladas con renovadas características clasicistas a nivel arquitectónico y ornamental (Martínez Ripoll, 2004: 45-49; Hernández Albaladejo, 2006: 69-85). De entre todos ellos hace un mayor hincapié en el templo de San Lorenzo, donde se recoge la afirmación destacada por casi todos los conocedores de la carta, en la cual Rejón afirma haber llevado durante su estancia en Madrid una serie de diseños elaborados por Ventura Rodríguez para colaborar en su construcción. A manera de colofón, elaboró una última observación sobre la arquitectura civil. En concreto, resalta la fábrica del puente que atraviesa el río Segura, proyecto desarrollado durante la primera mitad del Setecientos; fue trazado e iniciado por Toribio Martínez de la Vega y, posteriormente, continuado y finalizado por Jaime Bort. Destaca, asimismo, las hornacinas con las estatuas de San Miguel y San Rafael, elaboradas por Joaquín Laguna (Hernández Albaladejo, 1975-1976: 111-118; Peña Velasco, 2001: 233-265). 


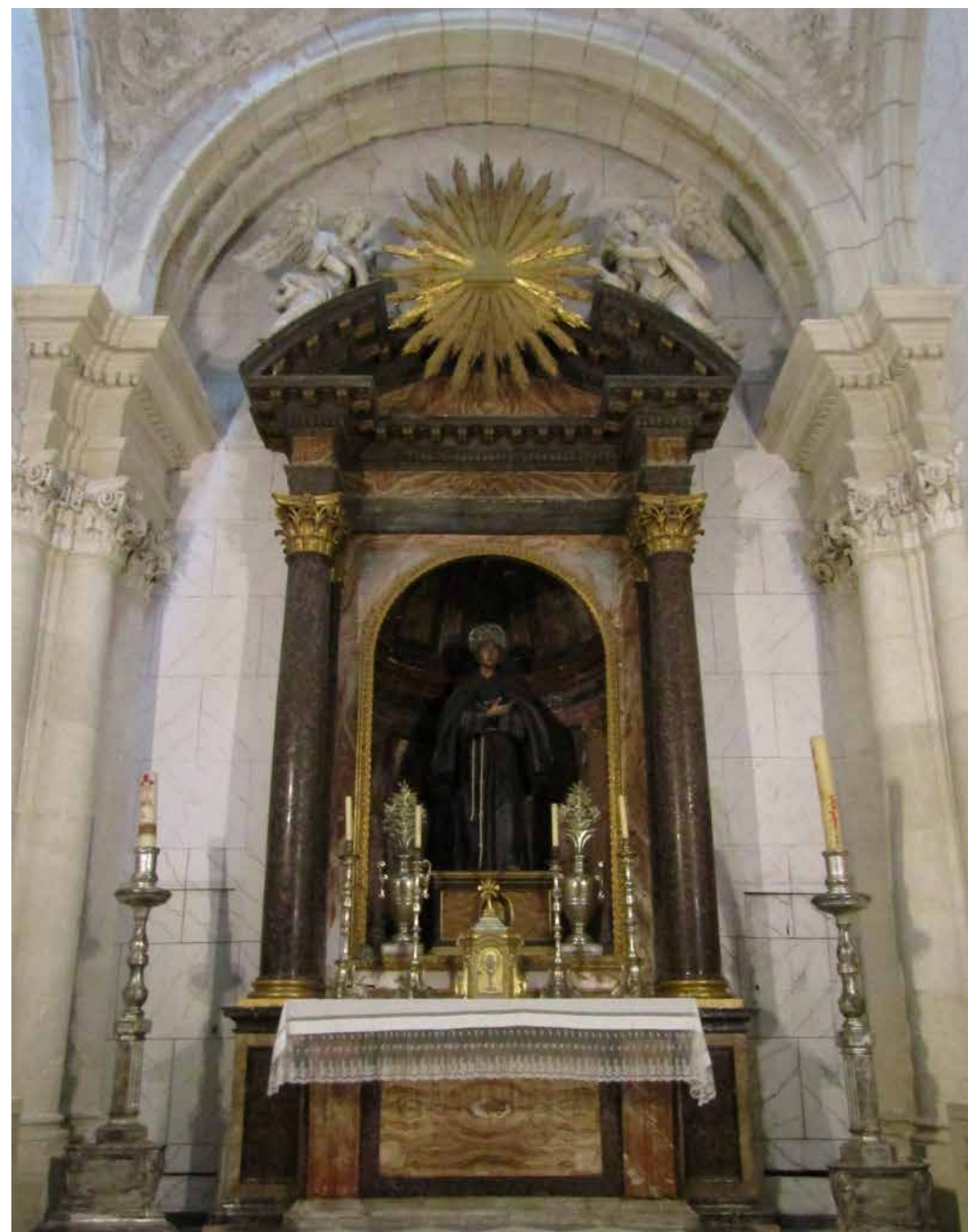

FIGURA 5. Detalle de la Capilla del Beato Fr. Andres de Hibernón. 1791. Catedral de Murcia. Fotografía propia

\section{CONSIDERACIONES FINALES}

El sucinto y escogido relato de las artes en la ciudad de Murcia que elaboró Diego Antonio Rejón de Silva muestra el objetivo principal de trasladar a su destinatario José Vargas Ponce una panorámica informativa muy particular sobre las principales obras artísticas y monumentales de la urbe. En concreto, el remitente buscó la exposición de un escenario en el que sobresaliesen los elementos artísticos derivados de la tradición renacentista y las renovaciones neoclasicistas. Un hecho que es palpable más allá de las noticias recogidas por Rejón, teniendo muy en cuenta los silencios de la carta, es decir, aquellas referencias no mencionadas a su interlocutor. Nos sirve de muestra en su "ligera descripción" como dejó a un lado las explicaciones acerca del imafronte catedralicio, una de las creaciones más suntuosas del siglo XVIII en la ciudad. Aunque sería respetada por viajeros y comentaristas posteriores, la mentalidad ilustrada no consideraba estimable la renovada fachada de la 
catedral (Hernández Albaladejo, 1990: 8-14; Torres-Fontes Suárez, 2003: 575-584). En este sentido, observamos la misma actitud estética que promovió en Ponz la realización de comentarios peyorativos en torno a las artes figurativas o elementos arquitectónicos y que fueron trasladados por correspondencia a Eugenio Llaguno; de una forma similar se pueden extrapolar a lo que, con mucha probabilidad, Rejón de Silva omitió a Vargas Ponce, al igual que ocurre con la descripción de la fachada. De hecho, la actitud de Rejón se puede equiparar a la de Ceán Bermúdez en las notas manuscritas de su viaje por la región murciana acompañado por Juan de la Peña- donde aprovechó para mostrar su opinión sobre la sociedad, economía, cultura, además de la arquitectura y el arte, aprovechando para arremeter contra el tardobarroquismo; salvándose la circunstancia de que dejó a un lado sus comentarios en torno a lo que podría considerarse, en palabras de Úbeda de los Cobos, algún vestigio clásico (2001: 364) ${ }^{13}$. La alteración severa de los conceptos fundamentales de la arquitectura y las artes figurativas clásicas no promulgaba con los nuevos valores que, refrendados por el gobierno y la monarquía, se comenzaron a ejecutar a través de los proyectos academicistas. Con ello se buscaba asentar y desarrollar en todo el territorio español una corriente crítica de pensamiento frente a las experiencias artísticas heredadas del Barroco (Galera Andreu, 1996: 13-20). En este sentido, la actitud de Rejón de Silva en su discurso obviando totalmente la fachada de la catedral nos demuestra su posicionamiento claro en contra de todo aquel legado artístico que no se sitúe en las líneas directrices del buen gusto.

De igual modo, no se dedicó solamente a aportar una visión ajustada de las artes figurativas o monumentos de la ciudad de Murcia, sino que en aquellos casos en los cuales no se hallaba capacitado para otorgar una descripción fidedigna, buscó la equiparación más similar a los modelos preferentes de la estética dieciochesca. Una actitud reflejada a lo largo de la breve narración, evocándose los nombres de Rafael o Murillo como autoridades artísticas presentes en la tradición artística murciana. Con ello aseguraba su comparación a través de un arquetipo de la pintura renacentista, defendido por Mengs, y otro de los baluartes de la pintura aurisecular hispana. Unas analogías de dudosa credibilidad pero que lograban trasladar una idealización de las obras a su receptor y, con ello, se subrayaba la singularidad de las obras que albergaba la urbe. Así, el enfoque crítico manifestado por Rejón de Silva le compromete con los postulados estéticos defendidos por Mengs y el ideario académico. Buscó transmitir equiparaciones que fueran lo suficientemente vinculables con los paradigmas estéticos promulgados por el pintor bohemio, a los que debía gran parte de su bagaje teórico-artístico. En cierto modo, él mismo se dejó influenciar por el ideario del pintor filósofo y los conceptos fundamentales adquiridos por medio de la tratadística renacentista. No hemos de olvidar que Rejón de Silva fue el traductor de la edición francesa de los textos conjuntos de Leonardo y Alberti acerca de la pintura, de los comentarios al arte de la Antigüedad clásica de Winckelmann y, además, de un ejercicio poético-didáctico sobre la teoría de la pintura dieciochesca (Jaquero Esparcia, 2019: 232-254). En sus valoraciones acerca de las obras pictóricas descritas a lo largo de la breve carta se advierten las preferencias por la pintura que evoca los fundamentos renacentistas. Una idéntica actitud se puede atisbar en los comentarios sobre escultura o arquitectura, estimándose o bien las creaciones originadas bajo los postulados clásicos o aquellas de nueva factura surgidas de esa misma raíz artística. De igual modo, lo vemos comprometido con la reivindicación teórica promulgada por los tratadistas hispanos del Setecientos en torno a los grandes maestros españoles de las artes del Siglo de Oro, en la línea crítica defendida por Ponz o Jovellanos. La apología, en cierto modo, ante los detractores que cuestionaban el desarrollo artístico de España y, asimismo, la propuesta de ejemplos en los que deberían mirarse los nuevos artífices con el fin de honrar al reino español con la gloria de las artes. Una actitud que desarrollaría de forma más amplia en

13 La descripción dice así: "Esta ciudad acaso será la mejor situada de toda la España, en una buena llanura y rodeada de su fertilísima y regada huerta en grano, moreras, naranjos, verduras exquisitas frutas y otras cosas. Su Catedral, aunque adornada exteriormente con una gran fachada llena de estatuas, columnas, arcos y ventanas, nichos, y otras mil cosas malas, y con su altísima torre, que aun no esta acabada, y que no es de pésima arquitectura, no se tiene cosa particular que notar, ni en su fabrica interior, ni en su adorno [...] el posito y lóndiga de esta ciudad es una obra seria y de muy buena arquitectura, como también la casa del contraste de la seda, en lo demás no halle cosa particular que notar respectiva a las bellas artes”. Ceán Bermúdez, Juan Agustín: "Viaje del Sr. Ceán por Andalucía, Murcia y Valencia”, Biblioteca Nacional de España, Sig. MSS/21454/5, fols. 14v. -15r. 
su poema didáctico sobre la pintura (Peña Velasco, 2013: 69-82).

Tras el análisis exhaustivo de la carta podemos afirmar que el comentario de la profesora Peña Velasco sobre las noticias poco acertadas de Rejón, sobre todo a la hora de declarar autorías o hacer comparaciones, se encuentra totalmente justificado. La información que se traslada a su interlocutor fue premeditada y pretende destacar los hitos histórico-artísticos que atestiguan los preceptos neoclásicos en la ciudad de Murcia, dejando a un lado las menciones a otros elementos que pueden tergiversar ese discurso. Ahora bien, esa percepción deliberada unida a los errores descriptivos demuestra una postura crítica clara y definida que, en cierto modo, puede llegar a tener una justificación. El perfil de amante de las Bellas Artes y no tanto de profesional que desempeñase una actividad artística en el cual debemos situar al autor de dichas noticias es muy relevante para entender las motivaciones que le llevaron a construir su particular interpretación del sobre el estado de las artes que le rodea. Hizo partícipe al receptor de sus ideas de una subjetiva composición del entorno artístico y monumental, tratando de que sobresaliesen los elementos ligados a la estética neoclásica más que con la completa realidad que le rodeaba, exponiendo su conocimiento del buen gusto artístico (Jacobs, 2000: 239-244). Una circunstancia comprensible si atendemos al ambiente cultural en el cual se había formado Rejón de Silva. Como ya hemos insistido, la autoridad de la doctrina mengsiana articula las bases de su pensamiento artístico: la imitación idealizada de la naturaleza, la conjunción de los paradigmas artísticos a nivel pictórico promulgados por Mengs -Rafael, Correggio y Tiziano-, la presencia de seleccionados modelos grecolatinos como garantes de la belleza -Hércules Farnesio, Apolo Belvedere, Laocoonte, entre otros-, o las proclamas clasicistas recogidas en las exposiciones y discursos públicos de la Academia terminaron por configurar la mentalidad de Rejón de Silva, pero también la de muchos de aquellos ilustrados que se acercaban al renovado discurso de las artes dieciochescas (Sambricio, 1976: 69-94; Bozal Fernández, 1989: 147-154). De hecho, los razonamientos de algunos de aquellos aficionados distan mucho de presentarnos un discurso unitario, confundiendo tanto conceptos básicos de la incipiente estética como los propios hechos históricos. Así, llegamos a reconocer unos patrones de conducta o actitudes que reducen la complejidad del panorama artístico a dos o tres normas fundamentales sobre las que asentaban su conocimiento. La literatura de la época nos da buena idea de ese perfil preciso de intelectual, aportándonos el juicio de Cadalso por medio de sus "eruditos a la violeta". Un posicionamiento que sería defendido por los propios artistas, considerando a la incipiente crítica de arte como una serie de veedores sin fundamento; tal y como observó Vega González, las exposiciones de pintura dieron voz a la figura del "mal observador", catalogado como mero charlatán e inexperto en la materia que enjuicia (2010: 93-97). De hecho, el propio Ceán dejó claro en el prólogo sus discrepancias contra los eruditos que se atreven a emitir estas valoraciones, es decir, cualquier "charlatán inexperto, llevado de las mas ligeras analogías, suele bautizar con los nombres de Rivera ó Murillo, de Monegro ó Becerra los quadros ó estatuas mas agenas", en contraposición de un sabio y juicioso observador (1800: I, XVIII). En este sentido, Rejón de Silva pecó en la carta a Vargas Ponce de querer demostrar una autoridad en la materia que no se hallaba totalmente consolidada. Actuó más desde una intención erudita, queriendo demostrar su conocimiento adquirido a través de la literatura artística y aplicarlo a ciertos casos prácticos, con un resultado más que cuestionable. Si bien es cierto que Rejón tenía una base teórica contrastada, como defiende Bedat en su estudio sobre la Academia de San Fernando, siendo del reducido número de consiliarios que acreditaban un conocimiento artístico (1989: 183-185).

Asimismo, no debemos olvidar la repercusión que pudo haber tenido dicha relación epistolar en los inmediatos proyectos literarios en torno a la Historia del Arte español. Bien es cierto que García López ya apuntaba el hecho de cómo Vargas transmitió diversas noticias a Ceán Bermúdez sobre aspectos artísticos y monumentales de Murcia en el año 1797, aproximadamente un año después del intercambio informativo con Rejón (2015: 135). En dicha carta se hace eco de la capilla de los Junterones, pero atendiendo más a aspectos históricos, sobre todo los orígenes de su creación, que a los artísticos. También recoge otros datos sobre artistas, oficios artesanos y algunos detalles más sobre una estatua de mármol que se situaba en "la parroquia de San Joseph, en Cartagena" (Fernández Duro, 1900: 82-83). Salvo la mención a la capilla de la catedral, no se hace eco de ninguna de las noticias recogidas por 
Rejón. Creemos, por lo tanto, que la información solicitada por Vargas Ponce tuvo un carácter ilustrativo y valorativo, siendo juzgado por la posterior visita a Murcia y Cartagena del propio solicitante. En definitiva y a modo de conclusión, podemos afirmar que Rejón de Silva trató de transmitir a su interlocutor, en cada uno de sus ejemplos, una serie de aspectos reseñables del desarrollo y progreso de las artes en Murcia que pudieran vincularse al debate estético de la época, condicionando con dicha visión neoclasicista su discurso sobre los elementos histórico-artísticos de la ciudad. Con ello, el autor se aseguraba la construcción de un relato o visión de conjunto en la cual se acentuasen los referentes que, a buen seguro, esperaba encontrar y valorar su receptor; gracias a ese más que intencionado posicionamiento nos ha legado una declaración muy palmaria de sus postulados artísticos.

De este modo, llegamos al final de estas líneas después de presentar una lectura exhaustiva de uno de los ejemplos de la correspondencia mantenida entre dos ilustrados que profesaron una clara devoción hacia las Bellas Artes hispanas y que contribuyeron desde su posición de aficionados a construir parte del debate de la historiografía artística del siglo XVIII. Hemos querido incidir con detalle en un ejemplo que, pese a ser una carta conocida por la investigación reciente en Historia del Arte, creemos que mediante su relectura crítica puede resultar de gran utilidad para entender mejor las pretensiones de ambos personajes y la estima profesada ante el estado de las artes de su época. En este caso concreto, hemos podido constatar el particular interés que demostraba la persona interrogada ofreciendo una composición idealizada lo más aproximada posible a los criterios estéticos de su entorno, todo ello articulado con el fin de complacer la experiencia de su amigo y facilitar su posible interés en futuros proyectos. Esperamos, por lo tanto, aportar más herramientas interpretativas para ahondar en los verdaderos motivos e inquietudes sostenidos por José Vargas Ponce y Diego Antonio Rejón de Silva a propósito de la arquitectura y las artes figurativas de la ciudad de Murcia. 


\section{BIBLIOGRAFÍA}

- Abascal Palazón, J. M. y Cebrían Fernández, R. (2010). José Vargas Ponce (1760-1821) en la Real Academia de la Historia. Madrid: Real Academia de la Historia.

- Agüera Ros, J. C. (1994). Pintura y sociedad en el siglo XVII. Murcia, un centro del Barroco español. Madrid: Real Academia Alfonso X el Sabio.

- Álvarez Barrientos, J. (2013). Los hombres de letras en sus cartas. Misantropía y comunicación en la teoría epistolar de Martín Sarmiento. En Padrón Fernández, R. (ed.). Las cartas las inventó el afecto: ensayos sobre epistolografía en el Siglo de las Luces. Santa Cruz de Tenerife: Idea, 17-46.

- Álvarez Cebrián, M. (2005). De la disertación sobre la belleza ideal de la pintura, escrita por D. Guillermo Lameyra. Quintana: revista de estudios do Departamento de Historia da Arte 4 (4), 235-248.

- Álvarez Cebrián, M. (2015). El gusto en el pensamiento ilustrado español la acepción estética (1738-1808) (tesis doctoral dirigida por Federico López Silvestre). Santiago de Compostela: Universidad de Santiago de Compostela.

- Andreu Candela, I. (2019). Aproximación a la correspondencia como fuente para el estudio del clima: la necesidad de un análisis léxico. Cuadernos de estudios del siglo XVIII, 29, 13-36.

- Arias de Saavedra Alías, Inmaculada (2009). Libros, lectores y bibliotecas privadas en la España del siglo XVIII. Chronica Nova, 35, 15-61.

- Azcárate, J. M. (1966). La valoración del gótico en la estética del siglo XVIII. Cuadernos de Estudios del Siglo XVIII, 18 (3), 525-549.

- Baquero Almansa, A. (1913). Catálogo de los profesores de las Bellas Artes Murcianos. Murcia: Sucesores de Nogués.

- Barocchi, P. (1984). Studi vasariani. Torino: Einaudi.

- Bédat, C. (1989). La Real Academia de Bellas Artes de San Fernando (1744-1808): Contribución al estudio de las influencias estilísticas y de la mentalidad artística en la España del siglo XVIII. Madrid: Fundación Universitaria Española - Real Academia de Bellas Artes de San Fernando.

- Belda Navarro, C. (1986). Arte y fiesta en Murcia con motivo de la beatificación de Andrés Hibernón (1791-1793). Carthaginensia, 2 (2), 279-300.

- Belda Navarro, C. y Hernández Albaladejo, E. (2006). Arte en la Región de Murcia. De la Reconquista a la Ilustración. Murcia: Comunidad Autónoma de la Región de Murcia.

- Bozal Fernández, V. (1989). Goya y el gusto ilustrado. Anuario del Departamento de Historia y Teoría del Arte, 1, 147-154.

- Candel Crespo, F. (2005). Deanes de la Catedral de Murcia (siglos XIII al XX). Murcia: F. Candel.

- Carrete Parrondo, J. (1976). Diego Antonio Rejón de Silva y la colección de Retratos de Españoles Ilustres. Revista de las Ideas Estéticas, 135, 211-216.

- Castillo Gómez, A. (2011). “Me alegraré que al recibo de ésta...” Cuatrocientos años de prácticas epistolares (siglos XVI a XIX). Manuscrits: revista d'historia moderna, 29, 19-50.

- Castillo Gómez, A. (2014). Sociedad y cultura epistolar en la historia (siglos xvi-xx). En Castillo Gómez, A. y Sierra Blas, V. (eds.). Cinco siglos de cartas. Historia y prácticas epistolares en las épocas moderna y contemporánea. Huelva: Universidad de Huelva, 25-56.

- Ceán Bermúdez, J. A. (2000). Diccionario histórico de los más ilustres profesores de las Bellas Artes en España (intr. J. M. Morán Turina). Madrid: Akal.

- Cook, E. (1996). Epistolary Bodies. Gender and Genre in the Eighteenth-Century Republic of Letters. Stanford: Stanford University Press.

- Crespo Delgado, D. (2012). Un viaje para la ilustración. El Viaje de España (1772-1794) de Antonio Ponz. Madrid: Marcial Pons.

- Crespo Delgado, D. (2017). Una carta inédita de G. M. de Jovellanos a J. A. Ceán Bermúdez (1 de septiembre de 1795). Cuadernos de estudios del siglo XVIII, 27, 407-414.

- Crespo Delgado, D. (2018). Dos cartas de Ceán Bermúdez para el origen de la historia de la arquitectura española. Cuadernos de estudios del siglo XVIII, 28, 419-428.

- Durán López, F. (1997). José Vargas Ponce (1760-1821). Ensayo de una bibliografía y crítica de sus obras. Cádiz: Servicio de Publicaciones de la Universidad de Cádiz.

- Fernández Duro, C. (1894). Noticias póstumas de D. José de Vargas Ponce y de D. Martín Fernández de Navarrete. Boletín de la Real Academia de la Historia, 24, 500-546.

- Fernández Duro, C. (1900): Correspondencia epistolar de D. José Vargas y Ponce y otros en 
materias de arte. Madrid: Real Academia de Bellas Artes de San Fernando.

- Franco Rubio, G. A. (2004). Militares ilustrados y prácticas de sociabilidad. Revista de Historia Moderna. Anales de la Universidad de Alicante, 22, 7-86.

- Galera Andreu, P. A. (1996). Arte neoclásico o el destierro de "Las tinieblas del mal gusto". Actas I Congreso "La Ilustración y Jaén". Homenaje a un ilustrado: José Martínez de Mazas. Jaén: UNED - Centro Asociado de la Provincia de Jaén, 13-20.

- Gállego, J. (1993). Una carta inédita de Goya sobre la restauración de pinturas. Academia: Boletín de la Real Academia de Bellas Artes de San Fernando, 76, 169-178.

- García López, D. (2015). "Era todo para todos": la construcción biográfica de Francisco Salzillo durante el siglo XVIII. Imafronte, 24, 103-164.

- García López, D. (2016). "Más parece hecha por una spciedad de lavorisos yndividuos, que por uno solo". El método de trabajo de Ceán Bermúdez. En Santiago Páez, E. (dir.). Ceán Bermúdez. Historiador del arte y coleccionista ilustrado. Madrid: Biblioteca Nacional de España - Centro de Estudios Europa Hispánica, 100-103.

- García López, D. (2020). "Revuelvo archivos y me lleno de polvo siempre con Vuestra merced en la memoria". Los estudios sobre bellas artes de José Vargas Ponce y Juan Agustín Ceán Bermúdez. Correspondencia (1795-1813). Gijón: Trea.

- García Sánchez, J. (2007). Cartas de Francisco Preciado de la Vega a Manuel de Roda (17651779). Academia: Boletín de la Real Academia de Bellas Artes de San Fernando, 104-105, 9-92.

- Gracia Menéndez, Á. (2016). El epistolario de Gaspar de Jovellanos sobre temas artísticos. Boletín Jovellanista, 16, 27-50.

- Gutiérrez-Cortines Corral, C. (1987). Renacimiento y arquitectura religiosa en la antigua Diócesis de Cartagena (Reino de Murcia, Gobernación de Orihuela y Sierra del Segura). Murcia: Colegio de Aparejadores y Arquitectos Técnicos.

- Henares Cuéllar, I. (1977). La teoría de las artes plásticas en España en la segunda mitad del siglo XVIII. Granada: Secretariado de Publicaciones de la Universidad.

- Hernández Albaladejo, E. (1975-1976). Puente Viejo de Murcia. Anales de la Universidad de Murcia. Filosofía y Letras, 34, 111-119.

- Hernández Albaladejo, E. (1990). La fachada de la Catedral de Murcia. Murcia: Colegio de Oficiales de Aparejadores y Arquitectos Técnicos.

- Hernández Albaladejo, E. (2006). Belluga y el mecenazgo eclesiástico. En Belda Navarro, C. y Gómez de Rueda, I. (coord.). Luis Belluga y Moncada: la dignidad de la púrpura. Murcia: Fundación Caja-Murcia, 69-85.

- Ibáñez Martínez, P. M. (1999). Fernando Yáñez de Almedina: la incógnita Yáñez. Cuenca: Servicio de Publicaciones de la Universidad de Castilla-La Mancha.

- Jacobs, H. C. (2001). Belleza y buen gusto. Las teorías de las artes en la literatura española del siglo XVIII. Madrid: Iberoamericana.

- Jaquero Esparcia, A. (2019). Poesía con fines didácticos sobre las artes. Génesis y recepción en la España de la Modernidad. Murcia: Editum Artes.

- Jorge Aragoneses, M. (1959). El Museo Diocesano de Murcia. Archivo Español de Arte, 32 (127), 267-269.

- León Tello, F. J. y Sanz Sanz, M. V. (1980). Tratados neoclásicos españoles de pintura y escultura. Madrid: Universidad Autónoma.

- Lepinette, B. (1999). La traducción del francés al español en el ámbito de la Historia (siglo XVIII). En Lafarga, F. (ed.). La traducción en España (1750-1830). Lengua, literatura, cultura. Lleida: Ediciones de la Universidad, 209-223.

- López Souto, N. (2019). Luces y sombras en la Europa de la Ilustración: la burla en las cartas entre José Nicolás de Azara y Giambattista Bodoni. Cuadernos de Ilustración y Romanticismo, 25, 309-337.

- Marías, F. (1989). El largo siglo XVI: los usos artísticos del Renacimiento español. Madrid: Taurus.

- Marqués de Seoane (1905). Correspondencia epistolar entre don José de Vargas y Ponce y don Juan Agustín Ceán Bermúdez durante los años de 1803 a 1805, existente en los Archivos de la Dirección de Hidrografía y de la Real Academia de la Historia. Boletín de la Real Academia de la Historia, 47, 5-60.

- Martínez Ripoll, A. (2004). Regalismo borbónico, reformismo eclesiástico y relaciones con Roma: el cardenal Belluga. En Alvar Ezquerra, A., Contreras Contreras, J. y 
Ruiz Rodríguez, J. I. (eds.). Política y cultura, en la época moderna (Cambios dinásticos. Milenarismos, mesianismos y utopias). Alcalá de Henares: Universidad de Alcalá, 29-49.

- Mestre Sanchís, A. (2000). La carta, fuente de conocimiento histórico. Revista de Historia Moderna, 18, 13-26.

- Mestre Sanchís, A. (2003). Apología y crítica de España en el siglo XVIII. Madrid: Marcial Pons.

- Molina, A. (2016). Retratos españoles con un epitome de sus vidas. Orígenes y gestación de una empresa ilustrada. Archivo Español de Arte, 89 (353), 43-60.

- Nadal Iniesta, J. (2018). Arquitectura y manifestaciones artísticas en la Murcia del Seiscientos. Murcia: Editum Artes.

- Nieto Alcaide, V., Morales Alfredo. J. y Checa Cremades, F. (1997). Arquitectura del Renacimiento en España 1488-1599. Madrid: Cátedra.

- Parlato, E. (2019). Origini e sviluppo dell'epistolografia artistica tra quattro e cinquecento. Dalle lettere alle loro raccolte. En Procaccioli, P. (ed.). L'epistologtrafia di Antico Regime. Sarnico: Edizione di Archilet, 299-312.

- Peña Velasco, M. C. (1985). Aspectos biográficos y literarios de Diego Antonio Rejón de Silva. Murcia: Colegio Oficial de Aparejadores y Arquitectos Técnicos.

- Peña Velasco, M. C. (1994). La controvertida intervención de Jaime Bort en la construcción de los porches del Almudí de Murcia. Verdolay. Revista del Museo de Murcia, 6, 173-180.

- Peña Velasco, M. C. (2001). El puente viejo de Murcia. Murcia: Servicio de Publicaciones de la Universidad de Murcia.

- Peña Velasco, M. C. (2013). Rejón de Silva y el discurso ilustrado sobre la escuela de pintura española. Atrio. Revista de Historia del Arte, 19, 69-82.

- Pérez Sánchez, A. E. (1976): Arte. En Azcárate Ristori, J. M. (coord.). Tierras de España. Murcia. Madrid: Fundación Juan March, 121-339.

- Pérez Sánchez, A. E. (2010). Pintura barroca en España (1600-1750) (ed. ampliada por Benito Navarrete Prieto). Madrid: Cátedra.

- Pérez Sánchez, M. (1995). El retablo y el mueble litúrgico en Murcia bajo la Ilustración. Murcia: Real Academia Alfonso X El Sabio.

- Portela Sandoval, F. J. (1978). Sobre la correspondencia de Ceán Bermúdez con Francisco Durán. Academia: Boletín de la Real Academia de Bellas Artes de San Fernando, 46, 191-208.

- Portela Sandoval, F. J. (1981). Varias noticias de artistas comunicadas por Justino Matute a Ceán Bermúdez. Academia: Boletín de la Real Academia de Bellas Artes de San Fernando, 53, 183-192.

- Reyes, A. (1968). La Catedral de Murcia. Primera mitad del siglo XVI. Murgetana, 29, 72-108.

- Rivas Carmona, J. y Cabello Velasco, R. (1900-1901). Los mármoles del Barroco murciano. Imafronte, 6-7, 133-142.

- Rodríguez G. de Ceballos, A. (2004). La capilla funeraria de los Vélez en la catedral de Murcia. Anuario del Departamento de Historia y Teoría del Arte, 16, 45-53.

- Romero Peña, A. (2012): “Cuadro de grosería, desunión y chismografía”: conflictos y divisiones internas en la Secretaria de Estado durante los últimos años del siglo XVIII. HISPANIA NOVA. Revista de Historia Contemporánea, 10, 32-53.

- Rubio Lapaz, J. (1993). Pablo de Céspedes y su círculo. Humanismo y Contrarreforma en la cultura andaluza del Renacimiento al Barroco. Granada: Universidad de Granada.

- Sambricio, C. (1976). Las “Oraciones” en la Academia de San Fernando. Revista de ideas estéticas, 136, 69-94.

- Sánchez Moreno, J. (1947). Notas sobre pinturas de los siglos XIV al XVII en Murcia. Anales de la Universidad de Murcia. Filosofía y Letras, 4, 361-375.

- Sánchez-Rojas Fenoll, M. C. (1987). La capilla del trascoro de la Catedral de Murcia. Homenaje al profesor Juan Torres Fontes. Murcia: Secretariado de Publicaciones de la Universidad, II, 1535-1545.

- Suárez Quevedo, D. (2004). Sobre Leon Battista Alberti en el sexto centenario de su nacimiento. La capilla Rucellai en San Pancrazio de Florencia. Anales de Historia del Arte, 14, 85-120.

- Tellechea Idígoras, J. I. (1969). Cartas inéditas de Manuel Salvador Carmona a Eugenio Llaguno Amírola (1780-1781). Academia: Boletín de la Real Academia de Bellas Artes de San Fernando, 28, 51-76.

- Torres-Fontes Suárez, C. (2003). La catedral de Murcia en las crónicas viajeras. En Ramallo Asensio, G. A. (coord.). El comportamiento de las catedrales españolas: del Barroco 
a los Historicismos. Murcia: Universidad de Murcia, Gobierno de la Región de Murcia, Consejería de Educación y Cultura, 575-584.

- Úbeda de los Cobos, A. (1995). La Prehistoria de la Historia del Arte. En Historiografía del arte español en los siglos XIX y XX. Madrid: Consejo Superior de Investigaciones Científicas, 123-125.

- Úbeda de los Cobos, A. (2001). Pensamiento artístico español del siglo XVIII. De Antonio Palomino a Francisco de Goya. Madrid: Museo Nacional del Prado.

- Vega González, J. (2005). Transformación del espacio doméstico en el Madrid del siglo XVIII: del oratorio y el estrado al gabinete. Disparidades. Revista de Antropología, 60 (2), 191-226.

- Vega González, J. (2010). Ciencia, arte e ilusión en la España ilustrada. Madrid: CSICPolífemo.

- Vega González, J. (2016). La Historia del Arte y su devenir en España. Circunstancias y reflexiones desde la práctica subjetiva. En Molina, A. (ed.). La Historia del Arte en España. Devenir, discursos y propuestas. Madrid: Polifemo, 23-173.

- Villella, Marzia (2002). Don Gil Rodríguez de Junterón. Committente Architettonico e Artistico tra Roma e Murcia. Anuario del Departamento de Historia y Teoría del Arte, 14, 81102.

- Winckelmann, J. J. (2014). Historia de las Artes entre los Antiguos (ed. de Alejandro Martínez Pérez). Madrid: Real Academia de Bellas Artes de San Fernando. 